\title{
A META-ANALYSIS OF RESEARCHES ON IMPLEMENTING THE SEMESTER SYSTEM: THE WAY AHEAD? \\ Netra Prasad Sharma*
}

\begin{abstract}
At present, Tribhuvan University (TU) seems to be in a sort of dilemma as to whether or not the semester system can be implemented in the programmes run by its faculties. Although TU authorities are still in extended discourse with the concerned stakeholders for the expansion of the semester programme, I sense some dilemma in the steps to be taken, the confusion propped by the fact that even the Master's programmes under the semester system have not been extended horizontally to the campuses other than the Central Departments at Kirtipur and the two other campuses in the valley only in science education. In this context, this article attempts to synthesize the research findings akin to the semester system and, based on the researches reviewed, points out the possible hurdles that need to be taken into consideration in advance and handled with great caution. The article argues that, despite some socioeconomic challenges, the semester system is better than the annual one and that it is the responsibility of all stakeholders to contribute to the implementation and success of the semester programmes.
\end{abstract}

\section{CONTEXT}

Taken to have originated from the German language, the term 'semester' is literally meant for 'half a year' (Sridevi, 2012). In the context of assessment and evaluation, the term is usually conceived in opposition to what we call the 'annual evaluation' system. The semester system entails evaluating students at least in a period of six months, although the term connotes the evaluation of students in three or four months or even more frequently. It is, therefore, that the terms like 'trisemester' or even 'quarter semester' are sometimes used. For instance, several US universities conduct their educational programmes under trisemester system, the semesters being Fall, Spring and Summer."Major essence of semester system is its formative, continuous and internal type of assessment that promotes teaching-learning process" (Ayub Buzdar, Ali, Akhtar, Maqbool and Nadeem, 2013: 79). On the other hand, the annual evaluation system involves evaluating students usually at the end of the year or an academic session. Although the differences between the

Mr. Sharma is Lecturer in English Education at Mahendra Ratna Campus, Tribhuvan University, Tahachal, Kathmandu, Nepal. 
two systems can be discussed at the philosophical as well as application level, the space available does not allow the discussion.

"Various academic and examination systems are in practice in educational institutions across the world. Presently, the semester system is the most widely adopted one" (Shoukat and Muhammad, 2015: 71). Even though the practices of both the systems of student evaluation (i.e. annual and semester) seem to be in vogue at present, the semester system is much more popular worldwide, the fact evident in, for instance, the south Asian context. The mandatory semester guidelines brought into effect by the University Grants Commission (UGC) of India requiring all the universities in the country to follow the guidelines from 2015 onwards are just one case. The circular of the UGC reads thus, "These guidelines shall apply to all undergraduate and postgraduate level degree, diploma and certificate programmes under the credit system awarded by the Central, State and Deemed to be universities in India" (UGC Guidelines, 2015: 1). The same trend prevails in the Universities of Pakistan, where, according to Mahmood (as cited in Ayub Buzdar, Ali, Akhtar, Maqbool and Nadeem, 2013: 79), in 2001, the Government of Pakistan asks its institutions of higher education to switch from the annual system to the semester system. Nevertheless, the University of Agriculture had adopted the semester system in 1968, Quaid-e-Azam University in 1971 and University of Karachi in 1974. The National Committee on Examination System (2006), in a set of guidelines, recommends that "all higher education institutions should gradually switch over for the semester of examination to attain harmony and uniformity at national level" (as cited in Munshi, Javed and Hussain 2012: 82). At present, in Pakistan, all the institutions of tertiary education are heading for the semester system as far as their infrastructures allow them. Adhikari (2014: 11) mentions that this system has already been in effect in all the schools and universities in China, most of the universities in Bangladesh and some of the universities in Shrilanka. In the developed countries, the semester system has been in practice for long. For instance, in the United States, the responsibility of designing curriculum, teaching and evaluating students is designated to the individual educational institutions, which undertake the responsibilities in the spirit of the semester system.

The scenario of Nepal in regard to the semester system is, I think, interesting. In 1961, TU held its first examinations under the annual system which was replaced by the semester system $(40 \%$ internal evaluation and $60 \%$ external written examination) in 1973.Although the semester system has been sustaining in the technical institutes of TU till date, the four faculties regressed to the annual system in 1983. 
According to Chaudhary, Adhikari, Jnawali, Sharma, Subedi and Tripathi, (2013), a "task force" formed by TU in 2012 involving the authors themselves, submitted a research-based strategic plan that iterates the need for the reinstatement of the semester system in order to improve the academic programmes and to internationalize them. The plan envisages developing the University Campus, Kirtipur into a Centre of Excellence. As mentioned in Adhikari (2013: 8), the "TU policy and programmes" document of 2013 proposes to upgrade the quality of education in TU and to develop the University Campus into the Centre of Excellence, the policy which seems to be in continuation with Chaudhary et al.'s strategic plan and the announcement of the reinstatement of the semester programme by the then Vice Chancellor in an orientation seminar-cum-workshop programme for campus chiefs held in Pokhara on 11-13 August 2013. A step further, in accord with the item no. 1354 of the decisions made by TU Council (17 December 2013), TU reinstitutes the programme in University Campus, Kirtipur with a set of "semester operation guidelines" in 2014 aiming at expanding it first to all the Master's programmes in the Kathmandu valley and to the ones in rest of the country within the first few months of 2016.

A question arises here. Why has TU attempted to reinstate the same semester system that it has twice labeled "failure"? Yet, there appears no serious study at all on why the programme had failed twice before and what notable changes had taken place till then. I firmly hold that the public allegation "whimsical decision "should prove whimsical in itself, but the lack of strong research grounds might prop the public diction; if not, the decision seems to be made solely based on the perception of the worldwide trend for the semester and the success of the TU programmes like BBA and BIM. Whatever the grounds, it is commendable that the attempts of implementation of the system have succeeded to some extent in at least the Central Departments at Kirtipur. The exercise to expand the system both horizontally to all the campuses in the country and vertically to all the programmes run by TU still seem to be curtailed for reasons difficult to explicate in this space.

\section{STATEMENT OF THE PROBLEM}

Tribhuvan University seems to be in a dilemma as to the implementation of the semester system in its four faculties, the fact observed in its circularity of introducing the system, dropping it and again introducing. Behind this, either there is no required willpower of the TU authorities in implementing the semester system or, because of the characteristics inherent in the system itself; its implementation is a problem worldwide or at least in the developing countries like ours. Therefore, this research attempts to 
explore what the researches in the South Asian region indicate about the implementation of the semester system.

\section{OBJECTIVES}

The objective of this research is to explore the major recommendations of the researches as regards the implementation of the semester system and to locate the major considerations to be made in successfully implementing the semester system.

\section{METHODOLOGY}

Employing the qualitative paradigm, this study carries out the meta-analysis of 10 researches on the semester system. Collected based on accessibility and convenience, the researches represent the three countries, viz. Nepal, India and Pakistan, all South Asian countries. The metaanalysis is made based on the two major themes - the major "orientation" of the research findings (whether positive or negative towards the implementation of the semester system) and the main "considerations" that need to be made with serious caution while implementing the system. A point to be noted is that, in this research, the term "considerations" encompasses in it all the challenges and problems as well as the research findings leading against the semester system.

\section{RESULTS AND DISCUSSION}

The table that follows displays the data obtained on carrying out the meta-analysis of the researches: 


\begin{tabular}{|c|c|c|c|c|}
\hline $\mathbf{S N}$ & Study & $\begin{array}{c}\text { Coun- } \\
\text { try }\end{array}$ & $\begin{array}{l}\text { Orien- } \\
\text { tation } \\
\text { of } \\
\text { Results }\end{array}$ & Major Considerations \\
\hline 1. & $\begin{array}{l}\text { Munshi, Javed } \\
\text { and Hussain } \\
\text { ( 2012) }\end{array}$ & $\mathrm{P}$ & $\begin{array}{l}\text { Mostly } \\
\text { negative }\end{array}$ & $\begin{array}{l}\text { Favouritism, overburden, } \\
\text { training for teachers, } \\
\text { seriousness of students, time for } \\
\text { students, cost, dropouts }\end{array}$ \\
\hline 2. & $\begin{array}{l}\text { Pathak and } \\
\text { Rahman S (2013) }\end{array}$ & $\mathrm{I}$ & $\begin{array}{l}\text { Mostly } \\
\text { positive }\end{array}$ & $\begin{array}{l}\text { Resources, student orientation, } \\
\text { student anxiety over frequent } \\
\text { exams }\end{array}$ \\
\hline 3. & $\begin{array}{l}\text { Yousaf and } \\
\text { Hasim (2012) }\end{array}$ & $\mathrm{P}$ & $\begin{array}{l}\text { Mostly } \\
\text { positive }\end{array}$ & Academic burden, costing \\
\hline 4. & $\begin{array}{l}\text { Shoukat and } \\
\text { Muhammad } \\
(2015)\end{array}$ & $\mathrm{P}$ & $\begin{array}{l}\text { Mostly } \\
\text { positive }\end{array}$ & $\begin{array}{l}\text { Sociopolitical and } \\
\text { administrative set-ups }\end{array}$ \\
\hline 5. & Sridevi (2012) & I & $\begin{array}{l}\text { Incon- } \\
\text { clusive }\end{array}$ & $\begin{array}{l}\text { Time management, student } \\
\text { evaluation, teaching and } \\
\text { learning, practical aspect }\end{array}$ \\
\hline 6. & Pabla (2014) & $\mathrm{I}$ & Negative & $\begin{array}{l}\text { Workload, teaching hours, } \\
\text { teacher growth, student } \\
\text { evaluation and family-work } \\
\text { balance of teachers }\end{array}$ \\
\hline 7. & Bhattarai (2014) & $\mathrm{N}$ & $\begin{array}{l}\text { Mostly } \\
\text { positive }\end{array}$ & $\begin{array}{l}\text { Curriculum, time frame, policy, } \\
\text { workload, resources, } \\
\text { management and job } \\
\text { satisfaction of teachers }\end{array}$ \\
\hline 8. & $\begin{array}{l}\text { Chongbang } \\
\text { (2014) }\end{array}$ & $\mathrm{N}$ & $\begin{array}{l}\text { Mostly } \\
\text { positive }\end{array}$ & $\begin{array}{l}\text { Resources, evaluation criteria } \\
\text { and ethical consideration }\end{array}$ \\
\hline 9. & Sharma (2016) & $\mathrm{N}$ & $\begin{array}{l}\text { Mostly } \\
\text { positive }\end{array}$ & $\begin{array}{l}\text { Basic needs and resources, } \\
\text { effective and reliable } \\
\text { evaluation, clarity of vision and } \\
\text { mission, collaboration among } \\
\text { stakeholders, curriculum, } \\
\text { political influence, supervision } \\
\text { and control }\end{array}$ \\
\hline 10. & $\begin{array}{l}\text { Ayub Buzdar, } \\
\text { Ali, Akhtar, } \\
\text { Maqbool and } \\
\text { Nadeem (2013) }\end{array}$ & $P$ & $\begin{array}{l}\text { Mostly } \\
\text { positive }\end{array}$ & $\begin{array}{l}\text { Teacher training, time } \\
\text { management, feedback, } \\
\text { fairness, evaluation of teacher } \\
\text { performance, effective } \\
\text { monitoring, grade inflation }\end{array}$ \\
\hline
\end{tabular}

Note: $\mathrm{I}=$ India, $\mathrm{N}=$ Nepal and $\mathrm{P}=$ Pakistan

Munshi, Javed and Hussain (2012: 86-87) findings are mostly negative as regards the semester system. Firstly, their study $(58 \%$ 
respondents) shows that there are chances of favouratism and bias on the part of the teachers, the fact which is accepted by the teachers $(60 \%)$ themselves as they confess that they are influenced by local pressure groups. Secondly, more than $70 \%$ teachers express that their workload is increased as they have to work more for the results of the examinations themselves. Thirdly, they (62\%) also confess that their performance is affected due to the lack of required training. Fourthly, 56\% teachers strongly agree that the students do not become serious as they think that lenient teachers award marks even if their performance is not up to the mark. Another major finding is that $56 \%$ students point out the fact that they are unable to prepare for the exams due to the lack of preparation leaves. Other minor findings include the extra financial burden on students, lack of enough time for extra activities, dropout of students due to strict rules and regulations, etc.

Pathak and Rahman (2013) study with 133 students and 44 teachers shows mostly positive results about the semester system, except that the students expressed their discontentment at the way their evaluation, both "internal assessment and overall evaluation", is carried out. Another finding is concerned with the lack of required resources, especially ICT facilities that influence the student achievement itself. Similarly, the study also reveals the fact that the respondents need to be provided with the knowledge of the grading system as well as the overall evaluation system. In addition, the students also expressed that they have anxiety due to the frequency of their assessments.

Yousafand and Hasim (2012) study the differences between the annual and the semester systems in terms of 12 descriptors to which 50 students respond. The descriptors are concerned with grading criteria, scores, job opportunities, concept understanding, goal focus, variety in assessment, presentation skills, academic burden, continuous assessment, teacher consideration and concentration, learning, and costing. The results indicate that the semester system is much better than the annual one as the former is taken by respondents to be better in terms of 10 descriptors. The only responses that go against the semester system are academic burden and costing.

Shoukat and Muhammad (2015) study the opinions of students and teachers about the effects of the social and administrative environments on the functioning of the semester system. The opinions collected covered the themes like appropriateness of syllabuses, course coverage, regularity and punctuality of teachers, fairness in grading, teacher attitude, appropriateness of the semester system itself in the given social and administrative set-up, teacher stress and anxiety in the semester system, effects of external non-academic factors of various kinds, 
institutional priorities, mechanism for administrative monitoring, etc. On surveying the opinions, the researchers conclude that although majority of the respondents evince their satisfaction over the standard of knowledge and skills students attain in the semester system and the evaluation of students in terms of fairness, the sociopolitical and administrative set-ups need to be revamped in order to run the semester system in its true spirit.

Sridevi (2012) studies the attitude of teacher trainees and problems faced by teacher educators in the semester system. The themes of the study include general aspects, time factor, teaching learning, practical aspect of the system, internal assessment and evaluation. The responses of altogether 204 teacher trainees involved in the study fail to clearly state whether or not the semester system is the desired system of education. "It is found that majority of the teacher trainees have mildly positive and mildly negative attitude" (Sridevi, 2012: 1). Nevertheless, the fact that, as the data indicate, $34.2 \%$ of the respondents favour the semester programme, $65.8 \%$ remain uncertain and no respondent shows unfavourable attitude towards the programme can be interpreted as the positive attitude of the sample towards the semester system.

Chongbang (2014) compares the semester and the annual systems being practiced simultaneously in the Faculty of Education, TU. The research findings indicate that the semester system is better than the annual one in a number of senses such as classroom management and teacher performance, student achievement, satisfaction and motivation of students, student evaluation and so on.

Sharma (2016) explores the opinions of students and teachers in order to locate the issues and challenges in implementing the semester system in TU. The study concludes that, despite the several challenges prevailing in implementing the semester system, it was "taken positively by the two major stakeholders and that it had to be expanded both horizontally and vertically" (p. 45). Nevertheless, the stakeholders pointed out various challenges such as unavailability of basic needs and resources; problem in effective and reliable evaluation; lack of clarity in vision and mission, collaboration among stakeholders, supervision and control, efficiency of curricula; political influence; etc.

Bhattarai (2014) studies the attitude of TU teachers towards the semester system. He surveys the opinions of 60 teachers teaching in the four faculties about different issues akin to the semester system. The issues include the attitude of the teachers towards the system itself, its management and implementation, job satisfaction of teachers, teaching methods, evaluation and feedback, and availability of resources. He concludes that, in general, the teachers are positive 
towards the system but they express their discontentment over the management and job satisfaction.

Pabla (2014) surveys the opinions of 200 teachers in order to investigate whether or not the semester system is better than the annual one. The study includes the issues concerned with curriculum, teaching hours, growth of teachers, "work-family imbalance" and student evaluation. The researcher states that "the annual system of education, wherever it is being followed, is being much preferred to semester system by the college teachers of degree colleges despite good merits of the semester system" (p. 1). The research points out the problems such as workload of teachers, lack of opportunity for teachers' personal growth, insufficiency of contact hours in teaching, lack of enough time for student evaluation, and the problem in teachers' family-work balance. Therefore, the researcher concludes that the semester system "must be discarded keeping in view all the good points of our old aged, well managed and timely tested annual system of education for the betterment of Indian youth" (p. 6).

Ayub Buzdar, Ali, Akhtar, Maqbool and Nadeem (2013) study the assessment practices in the semester system. They collect the opinions of 450 students and 50 teachers about the issues like assessment practices and feedback from them, use of study guides and guess papers for exam preparation, role of assessment in student motivation for further study, students' familiarity with the assessment provisions, practice of unfair means in assessment, grievances over test instruments and marking or grading, mechanism for monitoring assessment practices, need for the revision of existing assessment practices, etc. The study concludes that "majority of students confirms there [sic.] satisfaction with the system" (p. 85). Although favouritism exists among the university teachers, $88 \%$ students and $86 \%$ teachers opine that the role of the teacher in assessment is encouraging for student learning. This indicates the positive perception of students and teachers about the assessment practices of the semester system. As the research reveals, teacher training, time management, feedback, fairness, evaluation of teacher performance, effective monitoring, grade inflation, etc. are the issues to be addressed with more seriousness.

\section{SUMMARY}

In summary, the study reveals that there are mixed results of the researches on the semester system. At the negative end of the pole lies Pabla (2014) whereas Chongbang (2014) and Yousaf and Hasim (2012) with a very few issues raised against the semester system lie at the positive end. Sridevi (2012) lies inconclusive in between. The rest of the studies, except Munshi, Javed and Hussain (2012), are positive towards the semester system. In terms of number, seven studies out of ten indicate 
that, even though there are some considerations to be made more seriously, the semester system is better than the annual one. Another noteworthy point is that all the three studies from Nepal are positive towards the system although the studies from India and Pakistan have mixed perceptions.

\section{CONCLUSION}

From the analysis of the researches, it is evident that there exists no unanimity as to whether or not the semester system is a sort of panacea for the treatment of the anomalies prevailing in higher education. Realities are relative and virtually the diversity of opinions is to be expected. Nevertheless, as Aslam et al. (as cited in Singh and Kumar, 2016: 90), from a study, conclude that the "semester system is perceived to be most effective way of effectual learning" (p. 90), I also do believe that the semester system, if applied in its true spirit, can prove itself superior to the annual system, the fact strongly reinforced by the worldwide trend for the system. The success of the BBA and the BIM programmes of TU (CERID 2013) and the research findings from Nepal reported above leave no dilemma for TU in its determination to implement the semester system. What it needs, I take for certainty, is its true commitment.

\section{WORKS CITED}

Adhikari, D. (2014). Tri. bi. ma semester pranalikachunautiabamawasarharu. TU bulletin special. 2014-15, pp. 7-15.

AyubBuzdar, M., Ali, A., Akhtar, J.H., Maqbool, S. \& Nadeem, M. (2013). Assessment of students' learning achievements under semester system in Pakistan. Journal of basic and applied scientific research. 3(6), pp. 79-86. Retrieved from $\mathrm{http}: / / \mathrm{www} . \mathrm{cscconline.org}$

Bhattarai, L. (2014). Attitude of university teachers towards semester system. Unpublished Mini-research Report. FOE, Dean's Office, TU.

CERID (2013). A study on effectiveness of BBA and BIM program implementation. Unpublished Report. CERID, TU.

Chaudhary, R.P., Adhikari, D.R., Jnawali, D., Sharma, L.N., Subedi, G. \& Tripathi, G.R. (2013). Centre of excellence initiative in higher education: The context of Tribhuvan University Nepal. TU bulletin special, 2013-14, pp. 138-153.

Chongbang, K.B. (2014). Comparative study of semester system and annual system of faculty of education. Unpublished Mini-research Report. FOE, Dean's Office, TU. 
http://www.nnm.ac.in/ugc\%20circular\%20\&\%20guidelines\%20on\%20cb cs\%20-\%2019012015.pdf

Munshi, P., Javed, H. \& Hussain, I. (2012). Examination in semester system: What is observation of faculty and students? The Sindh University Journal of education. 41, pp. 76-92. Retrieved from https://www.academia.edu

Pabla, M.S. (2014). A comparative study of semester system and annual system of education in India. Golden research thoughts. 3(10). Retrieved fromhttp://aygrt.isrj.org

Pathak, T. \& Rahman, M.A. (2013). Perception of students and teachers towards semester system: a study in some selected degree colleges of Nagaon town of Nagaon district of Assam. Journal of education and practice. 4(1), pp. 84-91. Retrieved from http://pakacademicsearch.com

Sharma, N.P. (2016). Issues and challenges in implementing the semester system in Tribhuvan University. Unpublished mini-research report. Centre for Research, TU.

Shoukat, L. \& Muhammad, W. (2015). Perception of teachers and students towards the functionality of semester system at university level in the context of Pakistani social and administrative set-ups. International journal of teaching and education. 3(4), pp. 68-80. doi: 10.20472/TE.2015.3.4.006

Singh, V.K. \& Kumar, P. (2016). Challenges in implementation of semester system in globalized world. International journal of applied research. 2(3), pp. 89-91. Retrieved fromwww.allresearchjournal.com

Sridevi, K.V. (2012). A study of attitude of teacher trainees and problems faced by teacher educators on semester system of B.Ed. programme in Kerala. Golden research thoughts. 1 (11), pp.1-5. Retrieved from http://aygrt.isrj.org.www.allresearchjournal.com

Yousaf, A. \& Hashim, M. (2012). A case study of annual and semester systems of examination on government college of management sciences, Peshawar, Pakistan. International journal of academic research in business and social sciences. 2(9), pp. 53-73. Retrieved from www.hrmars.com 